\title{
Subsequent childhood asthma and wheeze amongst small-for-gestational-age infants in Manitoba and India: an International Partnership Initiative
}

\author{
Jennifer LP Protudjer ${ }^{1,2^{*}}$, Pratibha Dwarkanath ${ }^{3}$, Anita L Kozyrskyj ${ }^{2,4}$, Krishnamachari Srinivasan $^{3}$, Anura Kurpad ${ }^{3}$, \\ Allan B Becker ${ }^{1,2}$
}

From AllerGen NCE Inc.'s Fifth Annual Research Conference: Innovation from Cell to Society

Québec City, QC, Canada. 7-9 February 2010

\section{Background}

Globally, asthma and wheeze are increasing. Concurrently, the incidence of infants born small-for-gestational-age (SGA) is rising. Evidence describing associations between these two conditions are conflicting. We sought to explore this phenomenon in two distinct populations: Manitoba, Canada and Bangalore, India.

\section{Materials and methods \\ 1995 Manitoba Birth Cohort nested case-control study: Gestational period and birth weight were extracted from hospital records and classified as per Canadian SGA guidelines. At 8-10 years, asthma status and presence of wheeze were ascertained via pediatric allergist assess- ment. Parental-reported data included wheeze (ever, current [past year], or during various activities) as per International Study of Allergies and Asthma in Children (ISSAC) questionnaire, and demographic data. Bangalore Cohort: Gestational period at birth and birth weight were measured. SGA babies were classified as per World Health Organization's SGA guidelines. At 2-7 years, presence of wheeze was ascertained via physician assessment/prescription record and ISAAC question- naire. Asthma status was not assessed. All data were analyzed using descriptive statistics and $x^{2}$ tests.}

* Correspondence: jprotudjer@mich.ca

'Manitoba Institute of Child Health, Winnipeg, Manitoba, Canada, R3E 3P4 Full list of author information is available at the end of the article

\section{Results}

In Manitoba, 725 children (56.0\% boys) were assessed. Mean gestational period was $39.5 \pm 2.12$ weeks (non-significant [NS] differences by gender). Mean birth weight was $3.38 \pm 0.64 \mathrm{~kg}$; girls were significantly smaller than boys ( $\mathrm{p}<0.006)$. $114(16.1 \%)$ children $(54.4 \%$ boys) were SGA. At ages $9.06 \pm 0.64$ years, $246(34.1 \%)$ of children (149 boys) had asthma. No associations were identified between SGA and asthma, or between SGA and wheeze, when considering both genders combined or amongst boys only. Girls who were SGA were significantly more likely to have wheeze-related sleep disturbances than girls who were non-SGA (OR 0.33; 95\% CI 0.12-0.94; $\mathrm{p}$ $<0.03$ ).

In Bangalore, 432 children (48.0\% boys) were assessed for wheeze-like symptoms. Mean gestational period was $38.68 \pm 1.62$ weeks and mean birth weight was $2.87 \pm$ $0.49 \mathrm{~kg}$ (both NS differences between genders). Participants' mean age was $3.78 \pm 1.30$ years. 130 (30.2\%) children (47.7\% boys) were SGA. $71(16.4 \%)$ of children (38.4\% boys) had a doctor diagnosis of wheeze. SGA children had twice the risk of developing wheeze at follow-up (OR 2.19; 95\%CI 1.30-3.68; p < 0.003). After stratification by gender, these associations were only significant amongst boys (OR 3.24; 95\% CI 1.44-7.31; p < 0.003).

\section{Conclusion}

Children born SGA are at higher risk of developing wheeze-like symptoms, especially among the Indian boys. There is a small, yet significant association between SGA and wheeze-related sleep disturbances in 
Manitoban girls. Understanding the associations between SGA and wheeze may lead to enhanced pediatric clinical assessments. Public policy ought to target prevention of SGA.

\section{Author details}

${ }^{1}$ Manitoba Institute of Child Health, Winnipeg, Manitoba, Canada, R3E 3P4. ${ }^{2}$ University of Manitoba, Winnipeg, Manitoba, Canada, R3E 3P4. ${ }^{3}$ St-John's National Academy of Health Sciences. Bangalore, Karnataka State, India, 560 034. ${ }^{4}$ University of Alberta, Edmonton, Alberta, Canada, T6G 2T4.

Published: 26 November 2010

doi:10.1186/1710-1492-6-S3-P36

Cite this article as: Protudjer et al:: Subsequent childhood asthma and wheeze amongst small-for-gestational-age infants in Manitoba and India: an International Partnership Initiative. Allergy, Asthma \& Clinical Immunology 2010 6(Suppl 3):P36.

Submit your next manuscript to BioMed Central and take full advantage of:

- Convenient online submission

- Thorough peer review

- No space constraints or color figure charges

- Immediate publication on acceptance

- Inclusion in PubMed, CAS, Scopus and Google Scholar

- Research which is freely available for redistribution

Submit your manuscript at www.biomedcentral.com/submit 